\title{
PENGARUH PENAMBAHAN TEPUNG RUMPUT LAUT HIJAU (Ulva lactuca L.) DAN TEPUNG SUKUN (Artocarpus altilis) TERHADAP KARAKTERISTIK FISIKOKIMIA DAN ORGANOLEPTIK MIE BASAH
}

\author{
[The Effect of Green Seaweed (Ulva lactuca L.) Flour and Breadfruit (Artocarpus altilis) Flour Addition on the \\ Physicochemical and Organoleptic Characteristics of Wet Noodle].
}

\author{
Sartika ${ }^{{ }^{*}}$, Tamrin $^{1}$, Sri Rejeki ${ }^{1}$ \\ 1Jurusan Ilmu dan Teknologi Pangan Fakultas Pertanian Univeristas Halu Oleo. \\ *Email: sartikatika79745@gmail.com (Telp: +6281343231626)
}

Diterima tanggal 27 Juli 2019

Disetujui tanggal 24 September 2019

\begin{abstract}
This study aimed to determine the effect of breadfruit flour and green seaweed flour formulation on the physicochemical and organoleptic characteristics of wet noodles. This study used a completely randomized design (CRD) using the formulations of wheat flour, breadfruit flour and green seaweed flour M1 (70:28:2), M2 (70:26:4), M3 (70:24:6), and M4 (70:22:8). The results show that the formulation of breadfruit flour and green seaweed flour had a very significant effect on improving the organoleptic characteristics of color, aroma, taste, and texture of wet noodles. The best product based on the organoleptic assessment was found in the M4 formulation (70\% wheat flour formulation, $22 \%$ breadfruit flour, and $8 \%$ green seaweed flour) with assessment scores of color, aroma, taste, and texture, reached 3.81 (like), 2.98 (slightly like), 2.92 (slightly like) and 3.84 (like), respectively. The chemical analysis shows that the best wet noodle product contaiend $57.68 \%$ water, $1.23 \%$ ash, and $0.09 \%$ crude fiber. The highest antioxidant activity was obtained in the M4 treatment, which reached $62.50 \%$. Based on the results of the study, the wet noodle product with the formulation of breadfruit flour and green seaweed flour was preferred by the panelists and met the national standards for ash and water contents.

Keywords: wet noodle, fermented cassava flour, breadtruit flour
\end{abstract}

\begin{abstract}
ABSTRAK
Penelitian ini bertujuan untuk menentukan pengaruh formulasi tepung sukun dan tepung rumput laut hijau terhadap karakteristik fisikokimia dan organoleptik mie basah. Penelitian ini menggunakan rancangan acak lengkap (RAL) dengan menggunakan formulasi tepung terigu, tepung sukun dan tepung rumput laut hijau M1 (70:28:2), M2 (70:26:4), M3 (70:24:6), M4 (70:22:8). Hasil penilaian menunjukan bahwa formulasi tepung sukun dan tepung rumput laut hijau berpengaruh sangat nyata terhadap peningkatan uji organoleptik warna, aroma, rasa dan tekstur mie basah. Berdasarkan penilaian organoleptik terdapat pada formulasi M4 (formulasi tepung terigu $70 \%$, tepung ubi sukun $22 \%$, dan tepung rumput laut hijau $8 \%$ ) dengan skor penilaian terhadap karakteristik organoleptik warna 3,81 ( suka), aroma 2,98 (agak suka), rasa 2,92 (agak suka) dan tekstur 3,84 (suka). Nilai analisis kimia dari produk mie basah terbaik meliputi : kadar air 57,68\%, kadar abu 1,23\%, kadar serat kasar $0,09 \%$. Aktivitas antioksidan tertinggi pada perlakuan M4 (terigu $70 \%$ : tepung sukun $22 \%$ : dan tepung rumput laut $8 \%$ ) sebesar $62,50 \%$. Berdasarkan hasil penelitian, produk Mie basah formulasi tepung sukun dan tepung rumput laut hijau dapat diterima (disukai) oleh panelis dan memiliki kadar abu dan kadar air yang telah memenuhi standar SNI.
\end{abstract}

Kata kunci: mie basah, tepung sukun, tepung rumput laut hijau. 


\section{PENDAHULUAN}

Secara umum mie menggunakan tepung terigu yang bahan bakunya masih diimpor. Sampai saat ini terigu merupakan bahan utama dalam pembuatan mie, biskuit dan cookies. Menurut Asosiasi Produsen Tepung Terigu di Indonesia (Aptindo), impor gandum Indonesia untuk tahun 2007 mencapai 8,79 juta/ton. Hal tersebut menunjukkan ketergantungan Indonesia terhadap gandum dapat dikatakan sudah tinggi. Mengingat Indonesia bukan negara penghasil gandum, untuk mengurangi impor tepung terigu perlu dicari bahan yang dapat digunakan untuk mengganti terigu. Sehingga diperlukan alternatif bahan pengganti tepung terigu dalam pembuatan mie sehingga impor tepung terigu dapat dikurangi dengan memaksimalkan potensi umbi-umbian lokal menjadi tepung.Salah satu umbi lokal adalah ubi kayu.

Buah sukun merupakan buah yang tinggi akan karbohidrat sebagai sumber energi namun pemanfaatannya sebagai alternatif makanan pokok yang masih belum dimaksimalkan padahal keberadaannya melimpah. Produksi sukun di Indonesia terus meningkat dari 35.435 ton pada tahun 2000 menjadi 92.014 juta/ton pada 2007 (Kemenpan, 2007). Sukun dapat dijadikan sumber pangan pokok alternatif karena kandungan karbohidratnya yang tinggi 27,88\% per $100 \mathrm{~g}$ buah (Adinugraha et al., 2012). Kandungan karbohidrat pada buah sukun setara dengan kandungan karbohidrat yang terdapat pada beras (Tridjaja, 2003) Buah sukun mengandung lemak dan protein yang rendah dibandingkan dengan tepung terigu (Persagi, 2009).

Rumput laut merupakan bahan baku pangan hasil perairan yang tinggi kandungan gizinya namun masih perlu untuk dieksplorasi lebih lanjut potensinya. Rumput laut telah umum digunakan senagai makanan dinegaranegara Asia termasuk Indonesia. Rumput laut hijau mempunyai kelimpahan yang sangat tinggi di Indonesia, terutama jenis Ulva sp., Caulepran sp., Halimeda sp. Kandungan serat kasar rumput laut U. lactuca yaitu 7-13\% (Mahasu, 2016). Serat merupakan komponen penting pada diet manusia. Kebiasaan mengkonsumsi serat sangat bermanfaat bagi orang obesitas dan penderita diabetes melitus tipe 2 (Nufus et al., 2017). Serat membantu mengenyangkan perut, melindungi dari penyakit jantung dan kanker usus, menjaga fungsi saluran pencernaan agar tetap normal sehingga terhindar dari sembelit. Rumput laut juga membantu pengobatan tukak lambung, radang usus besar, susah buang air besar, dan gangguan pencernaan lainnya (Anggadiredja et al., 2006).

Chang dan Wu (2008) melaporkan bahwa tekstur mie yang dihasilkan lebih baik pada mie yang mengandung rumput laut $4 \%$ dan $8 \%$ daripada tidak mengandung rumput laut. Hasil penelitian tersebut menunjukan bahwa penambahan rumput laut secara signifikan dapat mempengaruhi kualitas dantekstur mie yang 
dihasilkan menjadi lebih baik. Penambahan rumput laut pada pembuata mie rumput laut basah diharapkan akan diterima oleh masyarakat karena mie merupakan makanan yang disukai oleh sebagian besar masyarakat indonesia.

Mie merupakan salah satu makanan favorit masyarakat Indonesia yang berbahan dasar tepung terigu dengan tingkat konsumsi khusus produk mie basah pada tahun 2013 mencapai 19 miliar bungkus (BPS, 2013). Formulasi tepung sukun dan tepung rumput laut diharapkan akan meningkatkan mutu pada mie, sehingga dapat menjadi salah satu produk pangan alternatif yang praktis untuk semua kalangan dan dapat diterima di masyarakat. Berdasarkan uraian tersebut maka panelis melaporkan hasil penelitian tentang penambahan tepung rumput laut hijau (Ulva lactuca L.) dalam pembuatan mie basah yang dikombinasikan dengan tepung sukun (Artocapus altilis) dengan harapan akan meningkatkan mutu pada mie, sehingga dapat menjadi salah satu produk pangan alternatif yang praktis untuk semua kalangan dan dapat diterima di masyarakat.

\section{BAHAN DAN METODE}

\section{Bahan}

Bahan utama yang digunakan dalam pembuatan mie adalah tepung rumput laut hijau (Ulva lactuca), tepung terigu, tepung sukun (Artocapis Altilis), garam, telur ayam ras, dan air. Sedangkan Bahan-bahan untuk analisis kimia yaitu n-heksana (teknis), $\mathrm{NaOH}$ (Teknis), $\mathrm{HCl}$ (Teknis), $\mathrm{H}_{2} \mathrm{SO}_{4}$ (Teknis), alkohol (Merck), metanol (Teknis) dan DPPH (1,1-difenil-2-pikrilhidrazil) (Sigma).

\section{Tahapan Peneltian}

\section{Pembuatan Tepung Sukun (Suismono, 2008)}

Pembuatan tepung sukun dilakukan dengan buah sukun dicuci terlebih dahulu untuk menghilangkan tanah, pasir dan kotoran yang melekat, lalu dikupas menggunakan pisau (pengupasan harus cepat dan segera direndam dalam air sementara menunggu pengupasan buah lainnya). Buah sukun yang telah dikupas lalu dibelah dan dikeluarkan empulumya. Kemudian dilakukan blansing selama 10 menit. Buah kemudian disawut/dirajang kecil-kecil untuk mempermudah pengeringan. Hasil sawutan harus segera jatuh terendam air dan kemudian dipres untuk mengeluarkan senyawa phenol. Sawut basah hasil pengepresan dikeringkan dengan alat pengering 5 sampai 6 jam dengan suhu pengeringan 55 sampai $60^{\circ} \mathrm{C}$ atau dijemur sampai kadar air $14 \%$ sesuai dengan standar mutu tepung terigu (SNI 01-3751-2006). Hasil sawut kering kemudian diblender sampai halus dan disaring menggunkakan ayakan 80 mesh menjadi tepung sukun dan ditimbang. 


\section{Pembuatan Tepung Rumput Laut Hijau (Agusman et al., 2004)}

Rumput laut Ulva lactuca dicuci sebanyak 3 kali kemudian ditiriskan lalu dikeringkan menggunakan alat oven pada suhu $60^{\circ} \mathrm{C}$ selama 7 jam. Rumput laut yang telah kering dihaluskan menggunakan alat blender kemudian diayak menggunakan ayakan ukuran 80 mesh sehingga diperoleh tepung rumput laut hijau Ulva lactuca.

\section{Pembuatan Mie Basah (Syamsidar, 2012)}

Pembuatan mie basah dilakukan dengan cara pecampuran, roll press (pembentukan lembaran), pembentukan mie, perebusan pendinginan hingga pengemasan. Pada tahap pertama tepung sukun, tepung terigu dan tepung rumput laut hijau dicampurkan kemudian ditambahkan air $50 \mathrm{~mL}$, garam $1 \mathrm{~g}$, dan telur $5 \mathrm{~g}$. Setelah adonan kalis, dibuat lembaran tipis. Lembaran-lembaran tersebut kemudian dimasukkan ke dalam rol pencetak mie dan kemudian direbus selama 10 menit.

\section{Penilaian Organoleptik (Winarno, 2002)}

Penilaian organoleptik merupakan suatu metode pengujian yang didasarkan atas penilaian kesukaan terhadap produk. Uji dengan metode hedonik dilakukan pada 30 panelis tidak terlatih dengan menggunakan lima skala yaitu = 5 (sangat suka), (suka), 3 (agak suka), 2 (tidak suka), dan 1 (sangat tidak suka). Uji ini dilakukan terhadap penilaian warna, aroma, rasa dan tekstur dari produk mie basah yang dihasilkan.

\section{Analisis Sifat Fisik (Biliana et al., 2013)}

Analisis sifat fisik mie basah meliputi uji daya serap air dan uji daya kembang.

\section{Analisis kimia}

Analisis nilai kimia meliputi analisis kadar air menggunakan metode thermogravimetri (AOAC, 2005), analisis kadar abu menggunakan metode thermogravimetri (AOAC, 2005), analisis kadar serat kasar menggunakan metode refluks (AOAC, 2005).

\section{Uji Aktivitas Antioksidan (Molyneux 2004)}

Uji aktivitas antioksidan dengan memodifikasi DPPH(1,1-difenil-2-pikrilhidrazil). Sampel diekstrak dengan melarutkan $1 \mathrm{~g}$ sampel pada $100 \mathrm{~mL}$ methanol, selanjutnya disaring menggunakan kertas saring. Uji aktivitas antioksidan dilakukan pada sampel mie basah dengan membuat larutan induk konsentrasi 10000 ppm dari keempat sampel, lalu diencerkan menjadi 7500 ppm, 5000 ppm, 2500 ppm,1000 ppm, 750 ppm dan 500 ppm. Kemudian dipipet $4 \mathrm{~mL}$ dari masing-masing sampel lalu dimasukkan kedalam tabung reaksi dan ditambahkan masing-masing $1 \mathrm{~mL}$ larutan DPPH (1,1-difenil-2-pikrilhidrazil) lalu masing-masing sampel dikocok, setelah itu 
diinkubasi pada suhu $37^{\circ} \mathrm{C}$ selama 30 menit lalu diukur absorbansinya pada panjang gelombang $517 \mathrm{~nm}$. Absorbansi dari sampel mie basah yang diperoleh dibandingkan dengan absorbansi blanko, sehingga diperoleh \% aktivitas antioksidannya. Perhitungan persentase aktivitas antioksidan dilakukan menggunakan rumus berikut :

$\%$ Aktivitas Antioksidan $=\frac{\text { Asorbansi Blanko-Asorbansi Sampel }}{\text { Asorbansi Blanko }} \times 100 \%$

Nilai $\mathrm{IC}_{50}$ dihitung dengan menggunakan persamaan regresi linear, yaitu $y=a x+b$ dengan $y=50$ dan $\mathrm{X}=\mathrm{I} \mathrm{C}_{50}$

\section{Rancangan Penelitian}

Penelitian ini menggunakan rancangan acak lengkap (RAL) dengan 5 perlakuan yaitu M1 (tepung terigu $70 \%$ : tepung sukun $28 \%$ : tepung rumput laut hijau 2\%), M2 (tepung terigu $70 \%$ : tepung sukun $26 \%$ : tepung rumput laut hijau 4\%), M3 (tepung terigu 70\% : tepung sukun 24\% : tepung rumput laut hijau 6\%), M4 (tepung terigu 70\% : tepung sukun $22 \%$ : tepung rumput laut hijau 8\%) diulang sebanyak 3 kali sehingga diperoleh 15 unit percobaan. Rancangan formulasi ini berdasarkan hasil penelitian pendahuluan.

\section{Analisis Data}

Analisis data dilakukan menggunakan analisis ragam (ANOVA). Hasil analisis data memiliki nilai $F$ hitung lebih besar dari pada F tabel dilanjutkan dengan uji DMRT 0,05 (Duncan`s Multiple Range Test) pada taraf kepercayaan $95 \%$.

\section{HASIL DAN PEMBAHASAN}

\section{Uji Organoleptik}

Hasil rekapitulasi analisis ragam pengaruh penamhan tepung rumput laut hijau dan tepung sukun terhadap parameter kesukaan organoleptik yang meliputi aroma, rasa, tekstur dan warna produk mie basah disajikan pada Tabel 1.

Tabel 1. Rekapitulasi analisis ragam pengaruh pengaruh penambahan tepung sukun dan tepung rumput laut hijau terhadap karakteristik fisikokimia dan organoleptik mie basah.

\begin{tabular}{ccc}
\hline No. & Variabel Pengamatan & Hasil Analisis Ragam \\
\hline 1. & Organoleptik warna & $*$ \\
2. & Organoleptik aroma & $*$ \\
3. & Organoleptik rasa & $* *$ \\
4. & Organoleptik tekstur & $* *$ \\
\hline
\end{tabular}

Keterangan: ${ }^{* *}=$ berpengaruh sangat nyata $(P<0,01)$ 
Berdasarkan Tabel 1, diketahui bahwa perlakuan formulasi tepung sukun dan tepung rumput laut hijau berpengaruh sangat nyata terhadap karakteristik organoleptik warna, aroma, rasa dan tekstur produk mie basah yang dihasilkan.

\section{Warna}

Hasil uji lanjut duncan's multiple range test (DMRT 0,05$)$ pada taraf kepercayaan $95 \%$ formulasi tepung sukun dan tepung rumput laut hijau terhadap penilaian organoleptik warna mie basah disajikan pada Tabel 2.

Tabel 2. Rerata hasil penilaian organoleptik warna pada mie basah tepung sukun dan tepung rumput laut hijau.

\begin{tabular}{ccc}
\hline Perlakuan & Rerata organoleptik & Kategori \\
(T:TS:TR) $(\%)$ & Warna & Agak suka \\
\hline M0 (100) & $2,86^{\mathrm{a}} \pm 0,03$ & Agak Suka \\
M1 (70:28:2) & $3,37^{\mathrm{ab}} \pm 0,05$ & Agak Suka \\
M2 $(70: 26: 4)$ & $3,43^{\mathrm{ab}} \pm 0,14$ & Suka \\
M3 (70:24:6) & $3,81^{\mathrm{a}} \pm 0,12$ & Suka \\
M4 (70:22:8) & $3,76^{\mathrm{a}} \pm 0,24$ & 24
\end{tabular}

Keterangan : Angka-angka yang diikuti oleh notasi huruf yang berbeda menunjukan berbeda nyata berdasarkan uji DMRT 0,05 taraf kepercayaan 95\%.Tepung terigu (TT), Tepung sukun (TS), Tepung rumput laut hijau (TRLH)

Berdasarkan hasil penelitian, diketahui bahwa perlakuan M3 (penambahan tertinggi tepung rumput laut yaitu 8\%) Perlakuan tersebut berbeda nyata dengan perlakuan M0, tetapi berbeda tidak nyata dengan perlakuan M1,M2, dan M4. Hal tersebut karena semakin rendah penambahan tepung rumput (Ulva lactuca) pada mie basah, maka kesukaan panelis cenderung menurun. Hal tersebut diduga karena tepung rumput laut hijau menyebabkan warna mie yang dihasilkan menjadi hijau pudar dibandingkan kontrol ( $0 \%$ tepung rumput laut) yang warnanya kuning seperti mie pada umumnya. Tingkat kesukaan penelis terhadap warna mie pada berbagai perlakuan. Hal tersebut didukung dengan hasil penelitian Riyanto (2016) yang melaporkan bahwa penilaian panelis terhadap warna mie basah rumput laut yang terbaik diperoleh pada penambahan rumput laut terendah (10\%) sedangkan penambahan rumput laut yang lebih banyak mengakibatkan penurunan tingkat kesukaan konsumen. Sakinah (2012) melaporkan bahwa mie basah rumput laut hasil penelitiannya memperoleh tingkat penilaian netral yakni antara 2,67-2,85. Hasil penelitian Amelda (2019) melaporkan bahwa penilaian panelis terhadap warna tepung suweg memiliki tingkat penerimaan antara suka dan tidak suka (netral) dengan skor 2,67-2,85.

Hasil uji lanjut duncan's multiple range test (DMRT 0,05 ) pada taraf kepercayaan $95 \%$ formulasi tepung sukun dan tepung rumput laut hijau terhadap penilaian organoleptik aroma mie basah disajikan pada Tabel 3. 
Tabel 3. Rerata hasil penilaian organoleptik aroma pada mie basah tepung sukun dan tepung rumput laut hijau.

\begin{tabular}{ccc}
\hline Perlakuan & Rerata organoleptik & Kategori \\
$(\mathrm{T}=: \mathrm{TS}: \mathrm{TR})(\%)$ & Aroma & Agak suka \\
M0 $(100)$ & $2,78^{\mathrm{a}} \pm 0,13$ & Agak Suka \\
M1 $(70: 28: 2)$ & $2,74^{\mathrm{a}} \pm 0,12$ & Agak Suka \\
M2 $(70: 26: 4)$ & $2,78^{\mathrm{a}} \pm 0,20$ & Agak Suka \\
M3 $(70: 24: 6)$ & $2,69^{\mathrm{a}} \pm 0,10$ & Agak Suka \\
M4 $(70: 22: 8)$ & $2,98^{\mathrm{a}} \pm 0,47$ & .
\end{tabular}

Keterangan : Angka-angka yang diikuti oleh notasi huruf yang berbeda menunjukan berbeda nyata berdasarkan uji DMRT 0,05 taraf kepercayaan 95\%. Tepung terigu (TT), Tepung sukun (TS), Tepung rumput laut hijau (TRLH).

Berdasarkan hasil penelitian, diketahui bahwa perlakuan M4 (penambahan tertinggi tepung rumput laut yaitu sebesar 8\%) Perlakuan tersebut berbeda tidak nyata dengan perlakuan M0, M1, M2, dan M3. Hal tersebut disebabkan karena semakin tinggi penambahan tepung rumput laut hijau pada pembuatan mie basah pada penelitian ini memiliki aroma khas rumput laut yang dihasilkan semakin kuat. Mie basah pada penelitian ini memiliki aroma khas rumput laut yang timbul akibat dari adanya senyawa volatil pada bahan yang menguap (Rasminar et al., 2017). Hasil penelitian Sri et al. (2017) menujukan bahwa nilai rata-rata aroma tepung sukun yang diperoleh dari varetas Toddo'puli sebesar 2,88. Aroma tepung yang dihasilkan dalam penelitian ini yaitu beraroma khas sukun. Hasil penelitian Kurnia et al. (2015) menunjukkan bahwa nilai organoleptik aroma tertinggi terdapat pada perlakuan P2 yaitu sebesar 3,200 dan terendah terdapat pada perlakuan P1 yaitu sebesar 3,042. Hal ini disebabkan oleh penstabil gum arab mampu mempertahankan flavor dari bahan selama dikeringkan.

\section{Rasa}

Hasil uji lanjut duncan's multiple range test (DMRT 0,05 ) pada taraf kepercayaan 95\% formulasi tepung sukun dan tepung rumput laut hijau terhadap penilaian organoleptik rasa mie basah disajikan pada Tabel 4.

Tabel 4. Rerata hasil penilaian organoleptik rasa pada mie basah tepung sukun dan tepung rumput laut hijau.

\begin{tabular}{ccc}
\hline $\begin{array}{c}\text { Perlakuan } \\
\text { (T:TS:TR) }(\%)\end{array}$ & $\begin{array}{c}\text { Rerata organoleptik } \\
\text { Rasa }\end{array}$ & Kategori \\
\hline M0 (100) & $2,86^{a} \pm 0,05$ & Suka \\
M1 (70:28:2) & $2,76^{a} \pm 0,08$ & Suka \\
M2 (70:26:4) & $2,74^{a} \pm 0,14$ & Suka \\
M3 (70:24:6) & $2,73^{a} \pm 0,12$ & Suka \\
M4 (70:22:8) & $2,92^{a} \pm 0,11$ & Suka
\end{tabular}

Keterangan : Angka-angka yang diikuti oleh notasi huruf yang berbeda menunjukan berbeda nyata berdasarkan uji DMRT 0,05 taraf kepercayaan $95 \%$. Tepung terigu (TT), Tepung sukun (TS), Tepung rumput laut hijau (TRLH). 
Berdasarkan Tabel 4, diketahui bahwa perlakuan M4 dengan nilai sebeasr 2,92 (Suka) Perlakuan tersebut berbeda nyata dengan perlakuan $\mathrm{M} 0, \mathrm{M} 1$, tetapi berbeda tidak nyata dengan perlakuan $\mathrm{M} 2$, dan $\mathrm{M} 3$. Hal tersebut disebabkan karena semakin tinggi penambahan rumput laut (Ulva lactuca) menyebabkan nilai kesukaan penelis terhadap rasa semakin tinggi. Hal tersebut didukung dengan penelitian Riyanto (2006) yang melaporkan bahwa mie basah dengan penambahan rumput laut hijau sebesar 10\% lebih disukai dibandingkan penambahan yang lebih banyak. pada Hasil penelitian (Kurnia et al.,2015) melaporkan bahwa nilai organoleptik rasa tertinggi terdapat pada cookies dengan penstabil gum arab dengan skor 3,929. Hasil penelitian Dayan (2019) melaporkan penilaian organoleptik rasa tertinggi diperoleh pada perlakuan C4 (tepung ubi kayu 95\% dan rumput laut hijau 5\%) dengan skor 3,55 (suka), rasa yang dihasilkan pada produk cookies karena rasa khas rumput laut dan bahan tambahan yang digunakan.

\section{Tekstur}

Hasil uji lanjut duncan's multiple range test (DMRT 0,05 ) pada taraf kepercayaan 95\% formulasi tepung sukun dan tepung rumput laut hijau terhadap penilaian organoleptik rasa mie basah disajikan pada Tabel 5.

Tabel 5.Rerata hasil penilaian organoleptik teksturpada mie basah tepung sukun dan tepung rumput laut hijau.

\begin{tabular}{ccc}
\hline Perlakuan & Rerata organoleptik & Kategori \\
$(\mathrm{T}: T S: T R)(\%)$ & Tekstur & Suka \\
M0 (100) & $3,60^{\mathrm{a}} \pm 0,05$ & Suka \\
M1 (70:28:2) & $3,63^{\mathrm{a}} \pm 0,12$ & Suka \\
M2 $(70: 26: 4)$ & $3,69^{\mathrm{a}} \pm 0,11$ & Suka \\
M3 (70:24:6) & $3,70^{\mathrm{a}} \pm 0,07$ & Suka \\
\hline M4 (70:22:8) & $3,84^{\mathrm{a}} \pm 0,15$ & \\
\hline
\end{tabular}

Keterangan : Angka-angka yang diikuti oleh notasi huruf yang berbeda menunjukan berbeda nyata berdasarkan uji DMRT 0,05 taraf kepercayaan 95\%. Tepung terigu (TT), Tepung sukun (TS), Tepung rumput laut hijau (TRLH).

Berdasarkan hasil penelitian, diketahui bahwa perlakuan M4 (penambahan tertinggi yaitu sebesar 8\%) perlakuan tersebut berbeda tidak nyata dengan perlakuan M0, M1, M2, dan M3. Hal tersebut diduga karena penambahan tepung rumput laut menyebabkan tekstur mie yang dihasilkan berbeda dengan mie pada umumnya sehingga tingkat kesukaan panelis meningkat. dimana tekstur mie formulasi tepung rumput laut hijau elastik dan kenyal. Hal tersebut didukung dengan penelitian Riyanto (2006) yang melaporkan bahwa penggunaan tepung rumput laut hijau 10\% menghasilkan tekstur mie basah yang lebih lembut dibandingkan penggunaan tepung rumput laut hijau yang lebih banyak. Sakinah (2013) melaporkan bahwa tekstur mie dengan penambahan tepung rumput laut hijau yang lebih banyak. Hasil penelitian Kurnia et al. (2015) menunjukkan bahwa pada semua jenis penstabil yang digunakan, semakin tinggi perbandingan tepung terigu penstabil maka nilai uji organoleptik 
teksturnya semakin tinggi 2,917-3-100. Hasil penelitian Dayan (2019) melaporkan bahwa penilaian organoleptik tekstur cookies tertinggi diperoleh pada perlakuan C4 (tepung ubi kayu 95\% dan tepung rumput laut hijau 5\%( dengan skor 3,75 (suka), Hal ini dikarenakan cookies pada konsentrasi tepung rumput laut $5 \%$ memiliki tekstur yang lebih renyah dan agak lembut.

\section{Karakteristik Fisik Mie Basah Perlakuan Terbaik}

Berdasarkan hasil uji organoleptik mie basah, maka dapat ditentukan bahwa mie tepung sukun dan tepung rumput laut hijau terbaik terdapat pada perlakuan M4 dengan formulasi tepung terigu $70 \%$, tepung sukun $22 \%$ dan tepung rumput laut hijau 8\%. Hasil uji fisik mie basah M4 (perlakuan terpilih) disajikan pada Tabel 6.

Tabel 6. Hasil uji fisik pada mie basah tepung sukun dan tepung rumput laut hijau.

\begin{tabular}{ccc}
\hline Parameter $(\%)$ & M0 (Kontrol) & M4 (Terpilih) \\
\hline Daya Serap Air & $2,30 \pm 0,10$ & $0,85 \pm 0,09$ \\
Daya Kembang & $1,99 \pm 0,03$ & $1,65 \pm 0,11$ \\
\hline
\end{tabular}

Keterangan : Angka-angka yang diikuti oleh notasi huruf yang berbeda menunjukan berbeda nyata berdasarkan uji DMRT 0,05 taraf kepercayaan 95\%. Tepung terigu (TT), Tepung sukun (TS), Tepung rumput laut hijau (TRLH).

\section{Daya Serap Air}

Berdasarkan hasil penelitian, diketahui bahawa nilai daya serap air pada penelitian ini lebih rendah. Hal tersebut didukung hasil penelitian Nugrahani (2005), pada tingkat penambahan air dalam jumlah yang sama, tepung yang memiliki kandungan protein tinggi mempunyai daya serap air lebih besar dari pada tepung dengan kandungan protein rendah. Daya serap air menunjukkan keadaan mie setelah proses perebusan. Semakin tinggi nilai daya serap air maka mie akan semakin mengembang (Merdiyanti, 2008). Menurut hasil penelitian Amelda (2019) menyatakan semakin banyak penambahan rumput laut dalam adonan mie basah makan semakin rendah daya serap airnya. Nilai daya serap air tertinggi pada penelitian ini yaitu $99,25 \%$ terdapat pada perlakuan A1 (96\% tepung suweg dan $4 \%$ tepung rumput laut).

\section{Daya Kembang Mie}

Berdasarkan hasil penelitian, diketahui bahwa semakin banyak penambahan tepung rumput laut dalam adonan mie basah semakin rendah daya kembang mie. Semakin banyak penambahan tepung terigu maka daya kembang mie semakin naik. Tepung sukun dan tepung rumput laut tidak mengandung gluten seperti yang terdapat pada tepung terigu. Gluten memiliki sifat hidrofobik akan membentuk jaringan tiga dimensi sehingga akan mengikat air dan akhirnya volume dari produk mengembang. Menurut Hasil penelitian Amelda (2019) menyatakan daya kembang Mie basah kombinasi tepung suweg dan rumput laut dengan formulasi $A 0, A 1, A 2, A 3$, dan $A 4$ 
memiliki daya pengembangan berturut-turut $4,70 \%, 13,81 \%, 10,60 \%, 8,22 \%$, dan 6,98\%. Mie basah dengan formuasi A1 memiliki daya pengembang tertinggi yaitu $13,18 \%$.

\section{Nilai Kimia Mie Basah Perlakuan Terbaik}

Berdasarkan hasil uji organoleptik mie basah, maka dapat ditentukan bahwa mie tepung ubi kayu fermentasi dan tepung ikan teri terbaik terdapat pada perlakuan M4 dengan formulasi tepung terigu 70\%, tepung sukun $22 \%$ dan tepung rumput laut hijau $8 \%$. Nilai kimia mie basah formulasi M4 (perlakuan terpilih) disajikan pada Tabel 6.

Tabel 6. Nilai kimia pada mie basah tepung sukun dan tepung rumput laut hijau.

\begin{tabular}{cccc}
\hline \multirow{2}{*}{ Komponen (\%) } & \multicolumn{2}{c}{ Perlakuan } & \multirow{2}{*}{ *SNI (\%) } \\
\cline { 2 - 3 } & $\mathrm{M}_{0}($ kontrol) & $\mathrm{M}_{4}$ (terpilih) & $20-35$ \\
Kadar Air & $47,39 \pm 1,69$ & $57,68 \pm 1,80$ & Maks. 3 \\
Kadar Abu & $0,13 \pm 0,03$ & $1,23 \pm 0,17$ & \\
Kadar Serat Kasar & $0,08 \pm 0,07$ & $0,09 \pm 0,28$ & \\
\hline
\end{tabular}

Keterangan : *SNI 01-2987-1992, Tepung terigu (TT), Tepung sukun (TS), Tepung rumput laut hijau (TRLH).

\section{Kadar Air}

Berdasarkan hasil penelitian, diketahui bahwa kadar air produk mie basah yang dihasilkan dengan menggunakan formulasi tepung terigu 70\% : tepung sukun 22\% dan tepung rumput laut $8 \%$ (M4) sebesar $57,68 \%$. akan mengakibatkan umur simpan mie mentah relatif singkat. Jumlah air yang ditambahkan pada adonan ialah tergantung dari banyaknya jumlah penambahan rumput laut. Kadar air adonan mie basah ini sangat mempengaruhi tekstur mie yang dihasilkan. Hal ini disebabkan pemberian air diatur agar kadar air yang mengalami perebusan meningkat dengan waktu perebusan yang sama. Maka kadar air mie basah akan meningkat karena serat pangan dalam rumput laut juga semakin banyak. Hal ini sejalan dengan penelitian Hudaya (2002) pembuatan mie basah subtitusi tepung ganyong dan rumput laut memiliki kadar air dengan penambahan tepung rumput laut disebabkan karena daya serap air rumput laut sebesar $80 \%$. Sehingga semakin banyak tepung rumput laut yang diberikan maka kadar air juga semakin tinggi. Hal tersebut berpengaruh negatif terhadap mutu produk, sesuai pernyataan Winarno (2004) bahwa semakin banyak kandungan air pada bahan makanan, maka kemungkinan rusaknya oleh mikroba semakin besar sedangkan suatu bahan pangan yang rendah kadar airnya akan semakin lama rusak daripada bahan dengan kadar air tinggi pada produk mie basah akan menyebabkan mie basah kurang kenyal dan elastic. 


\section{Kadar Abu}

Berdasarkan hasil analisis kimia, diketahui bahwa kandungan kadar abu pada produk mie basah yang dihasilkan dengan menggunakan formulasi tepung terigu $70 \%$ : tepung sukun $22 \%$ dan tepung rumput laut $8 \%$ (M4) sebesar 1,23\%. Kadar abu mie basah yang telah ditetapkan SNI yaitu maksimum 3\%. Kadar abu mie basah pada penelitian ini lebih tinggi dibandingkan kadar abu mie basah dengan penambahan tepung sukun hasil penelitian Ottong (2017) yang kadar abunya sebesar 0,63\%. Hal tersebut diduga karena tepung sukun yang digunakan pada pembuatan mie basah M4 mengandung mineral yang lebih banyak. Kadar abu mie basah M4 serupa dengan mie basah pengaruh penambahan tepung sukun hal dan tepung jagung. Hal ini sejalan hasil penelitan Ngaropa (2017) yang kadar abunya sebesar 1,7\%.

\section{Kadar Serat Kasar}

Berdasarkan hasil penelitian, diketahui bahwa kadar serat produk mie basah yang dihasilkan dengan menggunakan formulasi tepung terigu $70 \%$, tepung sukun $22 \%$ dan tepung rumput laut $8 \%$ (M4) dengan nilai sebesar 0,09\% dibandingkan perlakuan kontrol (100\% tepung terigu) yang mengandung serat sebesar 0,08\%. Hal tersebut semakin tinggi serat yang terkandung dalam mie basah maka semakin baik untuk pencernaan. Perkembangan penelitian membuktikan bahwa meski tidak mengandung zat gizi, serat mempunyai fungsi yang tidak tergantikan oleh zat lainnya dalam memicu terjadinya kondisi fisiologis dan dan metabolik yang dapat memberikan perlindungan pada kesehatan saluran pencernaan, khususnya usus halus dan kolon (Kusharto dan Hilmansjah, 2005).

Kadar serat yang tinggi dalam bahan makanan dapat dikatakan menguntungkan karena bersifat positif terhadap metabolisme (Winarno, 2004). Hasil penelitian Riyanto (2006) yang melaporkan bahwa mie basah pengaruh penambahan tepung rumput $10 \%$ memiliki kadar serat $1,4 \%$ dan meningkat menjadi $1,5 \%$ pada tingkat pengaruh penambahan tepung sukun 20\%. Ottong (2017) melaporkan bahwa mie basah pengaruh penambahan tepung sukun 50\% dan tepung tempe 50\% memiliki kadar serat sebesar 3,83\%. Josep (2002) menyatakan bahwa singkatnya waktu transit makanan dengan kandungan serat tinggi dapat mencegah penyakit divertikulosis karena berkurangnya tekanan pada saluran dinding pencernaan.

\section{Analisis Aktivitas Antioksidan}

Hasil uji aktivitas antioksidan pada produk mie basah pengaruh penambahan tepung rumput laut dan tepung sukun disajikan pada Gambar 1. 
Berdasarkan Gambar 1 diketahui bahwa semakin banyak penambahan tepung rumput laut hijau maka semakin meningkat pula aktivitas antioksidan mie basah. Antioksidan merupakan senyawa pemberi elektron (donor elektron) atau reduktan. Senyawa ini memiliki berat molekul kecil, tetapi mampu menginaktivasi berkembanganya reaksi oksidasi, dengan mengikat radikal bebas dan molekul yang sangat reaktif. Akibatnya kerusakan sel dapat dihambat (Winarsi, 2007).

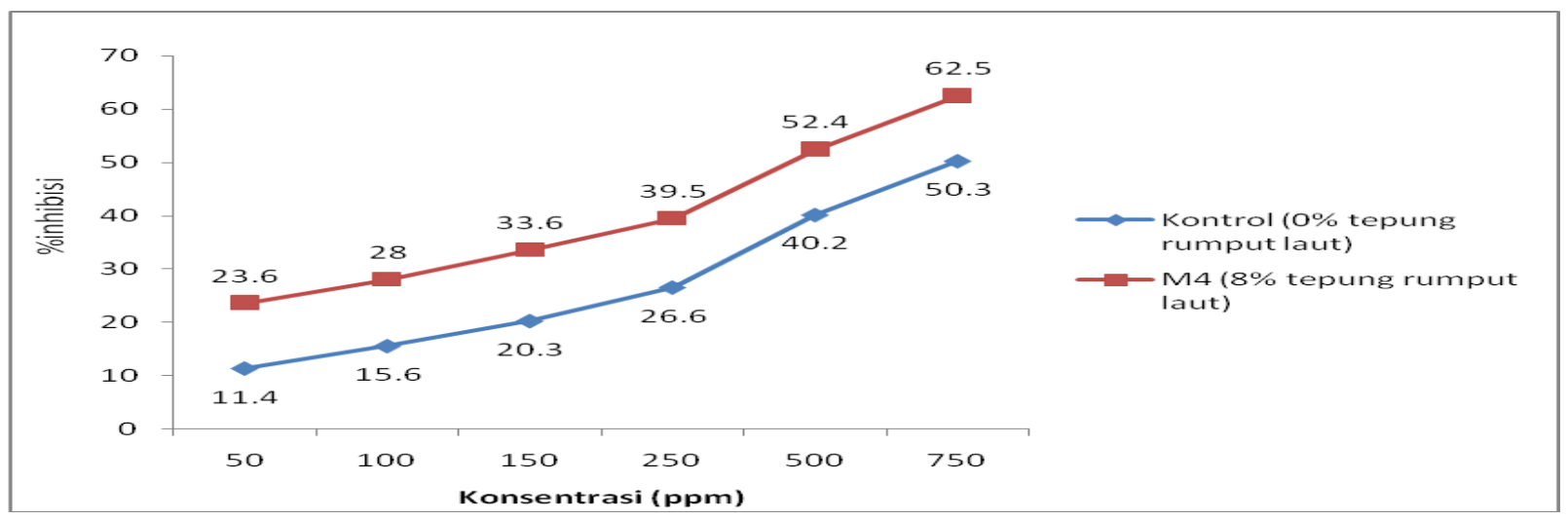

Gambar 1. Aktivitas Antioksidan Mie Basah tepung sukun dan rumput laut hijau

IPerlakuan M4 (Tepung terigu $70 \%$ : tepung sukun $22 \%$ : tepung rumput laut $8 \%$ ) memiliki $\%$ inhibisi radikal bebas sebesar 23,6 \%(kosentrasi 50 ppm), $28 \%$ (kosentarsi 100 ppm), 33,6 \% (kosentrasi 150 ppm), 39,5\% (kosentrasi 250 ppm), 52,4 \% (kosentrasi 500 ppm), 62,5\% (kosentrasi 750 ppm). Berdasarkan hasil yang diperoleh menunjukkan bahwa semakin tinggi kosentrasi (ppm) maka semakin tinggi pula \% inhibisinya.

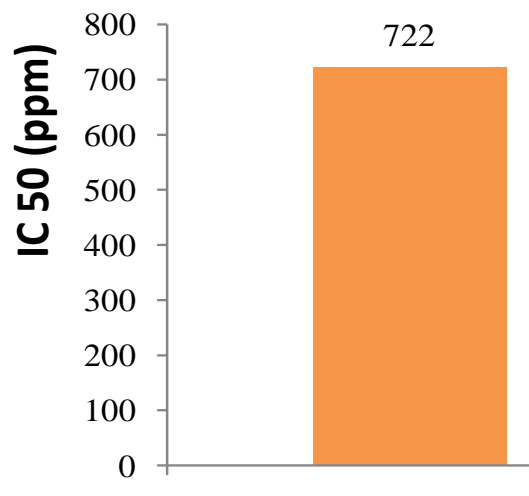

MO
487

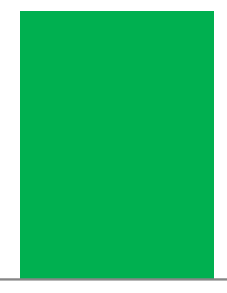

M4

Perlakuan

MO (0\% tepung rumput laut) M4 (8\% tepung rumput laut)

Gambar 2. Nilai $I_{50}$ produk mie basah kombinasi tepung sukun dan tepung rumput laut hijau 
Berdasarkan Gambar 2 diketahui bahwa mie basah perlakuan M4 (tepung terigu 70\% : sukun 22\% dan tepung rumput laut $8 \%$ ) memiliki nilai $\mathrm{IC}_{50}$ yang lebih baik dibandingkan kontrol $(0 \%$ tepung rumput laut). Berdasarkan hasil uji aktivitas antioksidan produk mie basah diketahui bahwa nilai $\mathrm{IC}_{50}$ pada perlakuan M4 (pengaruh penambahan tepung sukun 8\%) sebesar 487 ppm, perlakuan M0 (pengaruh penambahan tepung sukun $20 \%$ ) diperoleh nilai $I_{50}$ mie basah sebesar 722 ppm. Semakin tinggi penambahan tepung rumput laut $U$. lactuca pada pembuatan mie basah maka nilai $\mathrm{IC}_{50}$ semakin baik. Ekstrak Ulva lactuca hasil penelitian Arbi et al. (2016) memiliki IC 50 sebesar 60 ppm sedangkan mie basah hasil penambahan tepung sukun $U$. lactuca pada penelitian ini memiliki IC 50 sebesar 487 ppm.

\section{KESIMPULAN}

Terdapat pengaruh sangat nyata terhadap organoleptik warna, aroma, rasa dan tekstur mie basah. Berdasarkan uji organoleptik, formulasi terpilih yaitu M4 (tepung ubi sukun 22\%, tepung terigu $70 \%$, dan tepung rumput laut hijau 8\%). Karakteristik fisik pada mie basah perlakuan terpilih (M4) yaitu daya serap air sebesar 0,85\%, dan daya pengembangan 1,65\%. Sifat kimia mie basah perlakuan terpilih (M4) yaitu kadar air 57,68\%, kadar abu 1,23\%, kadar serat kasar 0,09\%, dan aktivitas antioksidan sebesar $62,50 \%$.

\section{DAFTAR PUSTAKA}

AOAC (Association of Official Analytical Chemist). 2005. Official Method of Analysis. AOAC Maryland International.

Amelda. 2019. Pengaruh Kombinasi Tepung Suweg (Amorphophalus faeoniifolius) dan Tepung Rumput Laut Hijau (Ulva lactuca) terhadap Karakteristik dan Fisikokimia Mie Basah. Skripsi. Fakultas Universitas Halu Oleo.

Aptindo. 2007. Konsumsi Tepung Terigu Nasional Indonesia. https//:www.newsimporgandum.co.id. Diakses Pada 6 Agustus 2018.

Agusma., Siti NK A dan Murdinah. 2014. Penggunaan Rumput Laut Eucheuma cottonii pada Pembuatan Beras Analog dari Tepung Modified Cassava Flour. Jurnal Perikanan. 9(1): 1-10.

Arbi B., Widodo FM. dan Romadhon. 2016. Aktivitas Senyawa Bioaktif Selada Laut (Ulva Lactuca) sebagai Antioksidan pada Minyak Ikan. Jurnal Saintek Perikanan. 12(1): 12-18. 
Biliana A., Waluyo S dan Suhandy D. 2013. Kajian Sifat Fisik Mie Basah dengan Penambahan Rumput Laut. Jurnal Teknik Pertanian Lampung. 4 (2) : 109-116.

Chang W. 2008. Pengaruh penambahan Rumput Laut Euchema cottonii Terhadap Mie Basah. Jurnal Teknologi dan Industri Pangan. 22(1): 66-72.

Dayan. 2019. Pengaruh Kombinasi Tepung UBi Kayu (Manihot utilissama pohl. Fermentasi dan Rumput Laut Hijau (Ulva Lactuca Linnaeus) terhadap Karakteristik Organoleptik, Serat dan Antioksidan Cookies.Skripsi. Fakultas Pertanian Universitas Halu Oleo. Kendari

Hudaya R N, 2002. Pembuatan mie basah dengan menggunakan tepung Ganyong (Canna) dan Tepung rumput laut (Ulva lactuca). Universitas Negeri Surabaya. Surabaya.

Mahasu NH., Jusadi D., Setiawati, M. dan Giri, I,N,A,A. 2016. Potensi Rumput Laut Ulva lactuca sebagai Bahan Baku Pakan Ikan Nila Oreochromis niloticus. Tesis. Institut Pertanian Bogor. Bogor

Merdiyanti. 2008. Paket Teknologi Pembuatan MieKe ring dengan Memanfaatkan Bahan Baku Tepung Jagung. Skripsi. Fakultas Teknologi Pertanian, Institut Pertanian Bogor. Bogor

Molyneux P. 2004. The Use of the Stable Free Radical Diphenylpicrylhydrazil (DPPH) for Estimating antiooxidan activity. Journal of Science Technology. 26(2):211-219.

Nufus C., Nurjanah dan Asadatun, A. 2017. Karakteristik Rumput Laut Hijau dari Perairan Kepulauan Seribu dan Sekotong Nusa Tenggara Barat sebagai Antioksidan. Jurnal PHPI. 20(3):210-218

Nugrahani. 2005. Perubahan karakteristik dan kualitas protein pada mie basah matang yang mengandung formaldehid dan boraks. Skripsi. Fakultas Teknologi Pertanian, Institut Pertanian Bogor. Bogor.

Ngaropa S. 2018. Pengaruh Komposisi Tepung sukun dan Tepung Jagung (Zea mays L) Terhadap Nilai Gizi dan Penilaian Organoleptik Mie basah. Jurnal Sains dan Teknologi Pangan. 3(1):60-70

Ottong Y., Tamrin dan Wahab D. 2017. Pengaruh Penambahan Tepung Tempe dan Tepun Rumput Laut (Eucheuma Cottonii) Terhadap Karakteristik Organoleptik Sagon Kelapa. Jurnal Sains dan Teknologi Pangan. 2(2):496-507.

Oktavia DR. 2008. Evaluasi Produk Good Time Mie basah di PT. Amott's Indonesia Sebagai Dasar Penentuan Nilai Tambah Produk. Skripsi. Institut Pertanian Bogor. Bogor.

Rachmawati R., Defiani M dan Suriani N. 2009, Pengaruh Suhu dan Lama Penyimpanan terhadap Kandungan Vitamin C pada Cabai Rawit putih (Capsicum frutescens). Jurnal Biologi. 13(1):36-40.

Rasmaniar., Ahmad dan Sukina B. 2017. Analisis Proksimat dan Organoleptik Biskuit dari Tepung Ubi Jalar Kuning dan Tepung sukun Sebagai Sarapan Sehat Anak Sekolah. Jurnal Sains dan Teknologi Pangan. 2(1):315-324. 
Riyanto B. dan Maya W. 2006. Mie basah Berkadar Serat Tinggi Pengaruh penambahan Tepung sukun dari Pengolahan Agar-Agar Kertas. Jurnal Teknologi Hasil Perikanan. 9(1):154-157.

Sayuti K. dan Rina Yenrina. 2015. Antioksidan Alami dan Sintetik. Andalas University Press Padang

Sakinah N. 2013. Pengaruh Pengaruh penambahan Tepung Terigu dan Tepung sukun dan Sargassum sp. Terhadap Kandungan Zat Gizi dan Kesukaan MP-ASI Mie basah Kaya Zat Besi. Journal of Nutrition College. 2(1):154-161.

Sunarsih. 2011. Prosedur Analisis Bahan Makanan dan Pertanian. Liberty. Yogyakarta

Syamsidar. 2012. Studi Pembuatan Mie Kering Dari Tepung Gadung. Afabeta. Bandung.

Winarno FG. 2004. Kimia Pangan Gizi, Teknologi, dan Konsumen. Gramedia Pustaka Utama, Jakarta

Winarsi H. 2007. Antioksidan alami dan radikal bebas potensi dan aplikasinya dalam kesehatan. Kanisius. Yogyakarta. 